\title{
Economic Sectors Value Added and Tax Revenues: Empirical Evidence from Jordan
}

\author{
Ali Mustafa Al-Qudah \\ Department of Finance and Business Economics \\ Faculty of Economics and Administrative Sciences \\ Al Al-Bayt University \\ Jordan
}

\begin{abstract}
The current study investigated the impact of economic sectors value added share of GDP represented by construction sector value added share of GDP (CONS), industrial sector value added share of GDP (INDS), mining and quarrying sector value added share of GDP (MINQ), Agricultural sector value added share of GDP (AGRIC) and services sector value added share of GDP (SERVICES) on tax revenues (TAX) in Jordan for the period 1990-2016. The study used unit root test, co-integration test and multiple linear regression model to examine the study hypotheses. The study found that there is a positive and significant impact of the construction sector value added share of GDP (CONS), industrial sector value added share of GDP (INDS), mining and quarrying sector value added share of GDP (MINQ) and services sector value added share of GDP (SERVICES) on tax revenues (TAX) in Jordan for the period 1990-2016. While it found that the agricultural sector value added share of GDP (AGRIC) has a negative and significant impact on tax revenues. The study found that economic sectors value added share of GDP represented by construction sector, industrial sector, mining and quarrying sector, agricultural sector and services sector are good determinants for tax revenues in Jordan.
\end{abstract}

Keywords: economic sectors, Value added, GDP, tax revenues, OLS, Jordan.

\section{1-Introduction}

Taxation is an important source of funding for the state's expenses and its various activities. It plays an important role in the economies of countries and is an important instrument of fiscal, economic and social policy. Taxes in non-oil developing countries are the main source of funding for government expenditures. Taxation is also a means of achieving the social goal of redistribution of income. Higher income earners have a higher tax, and taxes prevent or reduce undesirable activities by imposing high taxes on this type of activity. In addition to its use to find a balance in financial policies and to encourage investment and achieve economic objectives through the granting of exemptions or incentives for economic sectors or affect the pattern of consumption, production or savings through taxation, reduction or increase. Despite the positive aspects of taxes, if used correctly, countries suffer from low tax revenues, which is due to the characteristics of the state, its economy, tax systems, and the tax bracket. According to many researchers, tax revenues vary from country to country due to many factors such as economic development represented by GDP per capita, sectoral structure of GDP, external factors such as foreign direct investment, foreign trade and foreign aid, public policies represented by the exchange rate, Social factors are represented by educational level and population growth.

Jordan has suffered from a continuous deficit in the state budget for decades because of the increase in the state intervention in economic and social life, which led to an increase in public expenditure, which witnessed high growth rates since the Iraqi refugee crisis in 2003. The high prices of petroleum energy and the global financial crisis 2008 and its negative repercussions on the economies In addition to the crisis of the Syrian refugees and the decline in tax revenues due to tax evasion on the one hand and the decline in rates of economic growth on the other. The government has tended to amend the tax law several times during the past ten years, The high tax burden on companies and individuals alike has led to a decline in purchasing power and a decline in economic growth rates and thus a decline in tax revenues. The various economic sectors in countries are the main source of direct and indirect tax revenues for countries. On the basis of the above problem, this study was used to examine the impact of economic sectors value added share of GDP on tax revenues in Jordan during the period 1990-2016. 
The rest of the study is arranged as follow: section 2, literature review, Section 3, data and methodology, section 4, empirical analysis and results discussion, and section 5, conclusions.

\section{2-Literature Review}

In empirical literature, several variables considered as specific factors for tax revenues. The researchers included variables such as GDP per capita, The contribution of the agricultural sector as a share of GDP, the contribution of the industrial sector as a share of GDP, the contribution of the services sector as a share of GDP, economic openness and the ratio of foreign aid to GDP, total debt to GDP ratio, and other variables such as political stability and corruption. The results of the statistical tests were different due to their sensitivity to the group of countries and the time period of the samples. Zarra-Nezhad, Ansari Moradi (2016) they examined the determinants of tax revenue for 83 countries and they used Generalized Method of Moment regression to examine their hypotheses, they found that GDP growth, trade liberalization and democracy have a positive and significant impact on tax revenues, while they found that the agriculture share to GDP, exchange rate and urbanization have a negative and significant impact on tax revenues.

Ayenew (2016), investigated the determinants of tax revenue in Ethiopia for the period 1974-2013, he used Johansen maximum likelihood co-integration approach to examine study hypotheses. The results revealed that real GDP per capita income, foreign aid and industrial value added share of GDP positively and significantly affect tax revenue. While, inflation had a negative and significant effect. Ahmad, Ahmed, Mushtaq and Nadeen (2016) analyzed the socio economic determinants of tax revenue in Pakistan for the period 1975 to 2012, they applied Autoregressive Distributed Lag (ARDL) model to estimate the long run and short run empirical coefficients of the determinants. the results show that per capita GDP and tax compliance are positive and statistically significant determinants for tax revenue, While informal economy and narrow tax base are negative and statistically significant determinants of tax revenue in Pakistan.

Basirat, Aboodi and Ahangari (2014) investigated the impact of economic determinants on aggregate tax revenue in Iran by using annual time series data for the period 1974 to 2011 . Results show that exchange rate, imports, value added by agriculture and industry sector have significant effect on tax revenue. Castro and Camarillo (2014) analyze the effect of economic, structural, institution and social factors on tax revenue, for the 34 countries from Organization of Economic C0-operation and Development over the period 2001 to 2011. They used dynamic panel data techniques to examine the hypotheses, they results show that per capita income, the industrial sector and civil liberties have positive effect on tax revenue, while the agricultural sector and the share of foreign direct investment in gross fixed capital formation have negative effect. Muibi and Sinbo (2013) examined the impact of income level, exchange rate and inflation rate on tax revenue in Nigeria for the period 1970-2011. The output of the error correction model showed that the income level, exchange rate and inflation had a significant impact on tax revenues. Hakim and Bujang (2011). investigated the impact of tax revenue on major macro-economic factors. They used panel data of 120 countries, four type of economies; high income, high middle income, low middle income and poor countries. Panel data was used from 1960 to 2010. OLS technique was applied to examine hypotheses. The study emphasized that countries having high national income also had higher tax-to-GDP ratio relative to middle and low income economies. Inflation had significant and direct impact on tax-to-GDP ratio in all types of countries. the results show that inflation, FDI and savings had a causal relationship with tax rate in all countries.

Ghani (2011) examined the impact of both conventional and non-conventional determinants of tax to GDP ratio by using the panel data set of 104 countries over the period 1996-2005. the output of empirical analysis shows that Conventional factors represented by foreign aid, agriculture value added, GDP per capita, urbanization and trade openness are significant determinants of tax revenue. Moreover, non- conventional factors represented by rule of law and control of corruption are significant determinants of tax revenue. Ahmed and Mohammed (2010) investigated the determinants of tax revenues for 25 developing countries. They found that growth in import and industrial sector, services sector, budget deficit monetary growth had a positive impact on tax revenues. While The effects of the agriculture sector was insignificant. The growth in grants inversely affects tax revenues because governments in developing countries avoid unpopular imposing taxes for domestic production resource. Chaudhry and Munir (2010) empirically analyzed the determinants of low tax revenue in Pakistan for the period 1973 to 2009, by using multiple linear regressions. the results show that per capita income, share of agriculture in GDP ratio, share of services in GDP ratio, exchange rate, and foreign aid have a negative effects on low tax revenue, while the results shown the share of manufacturing in GDP ratio, monetization, inflation, 
External debt and foreign remittances have a positive effect on low tax revenue of Pakistan. the empirical results suggests that per capita income and exchange rate are negative determinants for low tax revenue, While Openness, Monetization and external dept are positive determinants for low tax revenue in Pakistan. Begum (2007). investigated the indicators of tax efforts for 11 low income economies. He used panel data for 15 years from 1991 to 2005. OLS technique was used and Hausman test was applied to choose between fixed effects and random effects models. The results show that money supply, public debt, trade openness and population growth rate had significant impact on tax-to-GDP ratio of these developing economies. Share of industry in GDP did not have any significant impact on tax collection. Gupta (2007) investigated the determinants of tax revenues efforts in developing countries, for the period 1980-2004. they used fixed effect model and random effect model. They found that per capita GDP, share of agriculture in GDP and trade openness had a positive and significant impact on tax revenues, while corruption had a negative and significant impact on tax revenues.

Agbeyegbe, Stotsky and Wolde Mariam (2004), examined the impact of trade liberalization and exchange rate on tax revenues for 22 Sub-Saharan African countries over the period 1980-1996. They used Panel data and Generalize Method of Moment regression to examine their study hypotheses. They found that trade liberalization had a strong impact on higher income tax revenues, while exchange rate showed a quite impact to lower tax revenues.

From the literature review we observed that the studies used different techniques to examine their studies hypotheses, such as panel data analysis, Fixed effect and random effect Models, Generalize Method of Moment regression, error correction model, Autoregressive distributive lag model and multiple linear regression, most of them found that per capita GDP, trade openness, exchange rate, foreign aid and industrial sector and services sector had a positive and significant impact on tax revenues, while they found that agriculture sector and corruption had a negative effect tax revenues. The literature reveals the following research gaps, almost nothing has been published to examine the impact of economic sectors value added share of GDP on tax revenues. since most of the previous studies focused on the macro-economic variables and politics, and some of them introduced one or two or all the sectors of industry, agriculture and services. There was no study on the impact of the different economic sectors on a particular argument. Although most of the tax revenues for countries are from direct and indirect taxes, license and fees imposed on various economic sectors. In the light of these knowledge gaps, the present study provides new empirical evidence on the impact of economic sectors value added share of GDP represented by construction sector value added share of GDP (CONS), industrial sector value added share of GDP (INDS), mining and quarrying sector value added share of GDP (MINQ), Agricultural sector value added share of GDP (AGRIC) and services sector value added share of GDP (SERVICES) on tax revenues (TAX) in Jordan for the period 1990-2016.

\section{Data and Methodology:}

\subsection{The Data}

This study used annually time series data for the period 1990-2016 collected from the Central Bank of Jordan database. Economic sectors value added share of GDP represented by construction sector value added share of GDP (CONS), industrial sector value added share of GDP (INDS), mining and quarrying sector value added share of GDP (MINQ), Agricultural sector value added share of GDP (AGRIC) and services sector value added share of GDP (SERVICES). Tax revenue (TAX) is measured by the ratio of tax revenues to GDP.

\subsection{Methodology}

\subsubsection{The Model Specification}

Depending on a review of previous studies such as Zarra-Nezhad, Ansari Moradi (2016); Basirat, Aboodi and Ahangari (2014); Castro and Camarillo (2014); Ahmed and Mohammed (2010) and Gupta (2007) Tax revenue is expressed as a function of several variables. GDP per capita, agricultural sector as a share of GDP, industrial sector as a share of GDP, economic openness and the ratio of foreign aid to GDP, total debt to GDP ratio. Based on the previous studies, this study examined the effect of added value as a percentage of the gross domestic product of five economic sectors, unlike previous studies that examined the effect of the macro variables. Some of them added the industrial sector and others the industry and agriculture sector, but this study was shortened to study economic sectors because of A significant impact on tax revenues and job creation and the large margin in the GDP, where the study adopted the following econometrics model.

$\mathrm{TAX}=\beta 0+\beta 1 \mathrm{CONSt}+\beta 2 \mathrm{INDSt}+\beta 3 \mathrm{MINQt}+\beta 4 \mathrm{AGRICt}+\beta 5 \mathrm{SERVICESt}+\varepsilon \mathrm{t}$ 
TAX is the ratio of tax revenues to GDP, CONS is the construction sector value added share of GDP, INDS is the industrial sector value added share of GDP,MINQ is the mining and quarrying sector value added share of GDP, AGRIC is the agricultural sector value added share of GDP and SERVICES is the services sector value added share of GDP, $\beta 0, \beta 1, \beta 2, \beta 3, \beta 4, \beta$ are parameters, $\mathrm{t}$ (time), $\mathrm{ct}$ ( error term). industrial sector value added share of GDP (INDS), mining and quarrying sector value added share of GDP (MINQ), Agricultural sector value added share of GDP (AGRIC) and services sector value added share of GDP (SERVICES). Tax revenue (TAX) is measured by the ratio of tax revenues to GDP.

\subsubsection{Study Variables}

\subsection{2,1 Dependent Variable}

Tax revenue: the total tax revenue share of GDP (TAX). Revenues collected by the State and government institutions on income, profits, taxes on goods and services, royalties, taxes on ownership, transfer of property and other taxes. The ratio of total tax revenues to GDP refers to the share of the State's product collected by the State and through taxes (Messere and Owens 1987).

\subsubsection{Independent Variables:}

1-Construction sector value added share of GDP (CONS): The construction sector in Jordan is an important economic sector because it is linked to a large number of other sectors and is characterized by a variety of subsectors, making it one of the most affected sectors by economic and social changes. The construction sector in Jordan witnessed high growth rates in the last two decades due to the increasing demand for real estate resulting from forced migration to Jordan as well as tourist activity. This variable helps to show the effect of growth in the construction sector on tax revenues in Jordan. The increase in growth in the construction sector increases the direct taxes through the income of companies and individuals and indirect taxes through sales tax, licenses, Fees and real estate registration.

2-industrial sector value added share of GDP (INDS): It consists mainly from manufacturing industries, it is considered as an important sector in the Jordanian economy for its significant contribution to the provision of employment opportunities and contribution to national exports and GDP. The development of this sector contributes to the increase of direct taxes on the income of companies and individuals and indirect taxes on sales, customs duties and licenses.

3- Mining and Quarrying sector value added share of GDP (MINQ): Mining Extraction Industries include: Phosphate Industry, Potash industry, Salt Industry and Carbonate Industry. Quarrying products and mines include: building stone, The rubble natural sand, aggregates, marble, granite and glass sand. Mining transformation industries in two branches : Chemical industries include: Fertilizer Industry, Manufacture of chemical acids and Manufacture of living and dehydrated lime Structural industries include: Cement industry, White cement industry, Rock wool industry, Porcelain (Chinese tiles and sanitary ware) and Building materials industry. the growth of this sector contributes to increase the direct taxes on income of firms and individuals, indirect taxes on sales and fees and license and customs duties.

4- Agricultural sector value added share of GDP (AGRIC): The agricultural sector is one of the important economic sectors in Jordan. Agriculture plays an important economic and social role for the rural communities. The agricultural sector consists of plant wealth and animal wealth, which constitute $55 \%$ of the agricultural sector, Where the poultry sector ranks first, followed by the cattle sector and then the sheep sector. The agricultural sector in Jordan faces problems and challenges such as drought, rainfall, agricultural land and scarcity of water resources. The agricultural sector contributes $2.8 \%$ of GDP and employs $3.5 \%$ of the total labor force. it is expected that the development of agricultural sector will not increase tax revenues this is due to that it is difficult to impose taxes on the agricultural sector because a large part of the agricultural sectors are small in size with a limited number of farmers who pay taxes on their income, agricultural products are exempt from indirect taxes, and a large part of the production is consumed and not marketed (Zarra-Nezhad, Ansari Moradi (2016).

5- Services sector value added share of GDP (SERVICES): The Kingdom's economy depends mainly on the services sector. It is the largest employer and a major supporter of monetary stability and the national currency. It can export its services through consumer access to tourism, education, health and services, financial and logistical support. 
It is the only supporter of the productive links of the agriculture and industrial sectors through the various infrastructure channels of roads, transportation, communications and water and electricity, and considered as the largest generator of growth in all countries of the world today. so it is expected that the development of this sector will increase the direct taxes on income of the firms as well as individuals, and will increase indirect taxes through sales tax, fees license.

\subsection{Study Hypotheses}

The study has the following alternative hypotheses:

H1: There is a significant impact for construction sector value added share of GDP (CONS) on tax revenues in Jordan for the period 1990-2016.

$\mathrm{H} 2$ : There is a significant impact for the industrial sector value added share of GDP (INDS) on tax revenues in Jordan for the period 1990-2016.

H3: There is a significant impact for the mining and quarrying sector value added share of GDP (MINQ) on tax revenues in Jordan for the period 1990-2016.

H4: There is a significant impact for the agricultural sector value added share of GDP (AGRIC) on tax revenues in Jordan for the period 1990-2016.

H5: : There is a significant impact for the services sector value added share of GDP (SERVICES). on tax revenues in Jordan for the period 1990-2016.

\section{Regression Analysis}

\subsection{Unit Root Test/ stationary Test}

The Augmented Dickey Fuller test (ADF) is used to test the stability for the annually time series of the study variables tax revenues (TAX), Construction (CONS), Industry (INDS), mining and Quarrying (MINQ), Agriculture (AGRIC) and services (SERVICES). The non-stability of the time series results in a spurious regression (Amassoma, 2011). From Table (1) the results of Augmented Dickey Fuller (ADF) unit root test, when we test for unit root test at level and (non, trend, trend and intercept) that all variables except mining and quarrying are not stationary at the level. The value of probability of the Augmented Dickey Fuller test (ADF) is greater than 5\%. Thus, we accept the null hypothesis that states that there is a unit root (time series is not stationary) for the study variables except mining and quarrying and then we re-test, and after taking the first difference we found through (Augmented Dickey Fuller test (ADF)) and from the probability value which were less than 5\%, thus rejecting the null hypothesis and accepting the alternative hypothesis that states that there is no unit root or the time series of the study variables are stationary. This enables us to avoid the problems of spurious regressions that are associated with non-stationary time series models.

Table 1: Augmented Dickey Fuller (ADF) Unit Root Test

\begin{tabular}{|l|l|l|l|l|l|}
\hline Variable & $\begin{array}{l}\text { Calculated ADF } \\
\text { Statistics }\end{array}$ & $\begin{array}{l}\mathbf{5 \%} \text { ADF Critical } \\
\text { Value }\end{array}$ & Probability & $\begin{array}{l}\text { Order of } \\
\text { Integration }\end{array}$ & $\begin{array}{l}\text { Stationary/ Not } \\
\text { Stationary }\end{array}$ \\
\hline TAX & -1.97558 & -2.98623 & 0.2949 & $\mathrm{I}(0)$ & N ot stationary \\
\hline CONS & -2.16307 & -3.6032 & 0.4882 & $\mathrm{I}(0)$ & Not stationary \\
\hline INDS & -1.79006 & -3.6032 & 0.6791 & $\mathrm{I}(0)$ & Not stationary \\
\hline MINQ & -4.28058 & -3.6032 & 0.0123 & $\mathrm{I}(0)$ & Stationary \\
\hline AGRIC & -1.09707 & -3.6032 & 0.9095 & $\mathrm{I}(0)$ & Not stationary \\
\hline Services & -2.13957 & -3.6032 & 0.5003 & $\mathrm{I}(0)$ & Stationary \\
\hline TAX & -5.48484 & -3.6122 & 0.0009 & $\mathrm{I}(1)$ & Stationary \\
\hline CONS & -7.5313 & -3.6122 & 0.0000 & $\mathrm{I}(1)$ & Stationary \\
\hline INDS & -5.18247 & -3.6122 & 0.0018 & $\mathrm{I}(1)$ & Stationary \\
\hline MINQ & -5.36314 & -3.62203 & 0.0013 & $\mathrm{I}(1)$ & Stationary \\
\hline AGRIC & -4.60966 & -3.6122 & 0.0063 & $\mathrm{I}(1)$ & Stationary \\
\hline SERVICES & -5.89849 & -3.6122 & 0.0004 & $\mathrm{I}(1)$ & \\
\hline
\end{tabular}




\subsection{Co-integration Test}

The Johansen co-integration test is applied to examine the long-run relationship between the study variables. The Trace value test in table (2) as well as Max-eigen value test in table (3) indicates no co-integration. This imply that there is no long run relationship between study variables tax revenues (TAX), Construction (CONS), Industry (INDS), mining and Quarrying (MINQ), Agriculture (AGRIC) and services (SERVICES) .

Table 2: Unrestricted Co-integration Rank Test (Trace).

\begin{tabular}{|l|l|l|l|l|}
\hline Hypothesized & & Trace & 0.05 & \\
\hline No. of CE(s) & Eigenvalue & Statistic & Critical Value & Prob.** \\
\hline None & 0.083612 & 2.008264 & 3.841466 & 0.1564 \\
\hline
\end{tabular}

Trace test indicates no cointegration at the 0.05 level

$*$ denotes rejection of the hypothesis at the 0.05 level

**MacKinnon-Haug-Michelis (1999) p-values

Table 3: Unrestricted Cointegration Rank Test (Maximum Eigenvalue)

\begin{tabular}{|l|l|l|l|l|}
\hline Hypothesized & & Max-Eigen & 0.05 & \\
\hline No. of CE(s) & Eigenvalue & Statistic & Critical Value & Prob.** \\
\hline None & 0.083612 & 2.008264 & 3.841466 & 0.1564 \\
\hline
\end{tabular}

Max-eigenvalue test indicates no cointegration at the 0.05 level

* denotes rejection of the hypothesis at the 0.05 level

**MacKinnon-Haug-Michelis (1999) p-values

\subsection{Multicollinearity Test}

Before regression analysis procedure we have to be sure that there is no Multicollinearity between independent variable, because in the case of high collinearity the estimated standard errors is high which makes $t$ values smaller and in such cases $R^{2}$ is high (Gujarati, 2004). Table (4) shows the results of the correlation coefficient which indicates no high correlation between the independent variables (no Multicollinearity) .

Table (4) correlation coefficient between independent variables

\begin{tabular}{|l|l|l|l|l|l|}
\hline & CONS & INDS & MINQ & AGRIC & SERVICES \\
\hline CONS & 1 & -0.10508 & -0.51298 & -0.28786 & 0.420562 \\
\hline INDS & -0.10508 & 1 & -0.01386 & -0.48564 & -0.1823 \\
\hline MINQ & -0.51298 & -0.01386 & 1 & 0.445107 & -0.2622 \\
\hline AGRIC & -0.28786 & -0.48564 & 0.445107 & 1 & -0.21801 \\
\hline SERVICES & 0.420562 & -0.1823 & -0.2622 & -0.21801 & 1 \\
\hline
\end{tabular}

\subsection{Multiple linear Regression Model Results}

\section{The Impact of Construction Sector on Tax Revenues}

The results of the regression reported in Table (5). The results indicate the construction sector (CONS) has a positive and significant impact on tax revenues since the coefficient of the construction sector is 2.7117 and the probability is 0.0242 , which means that if the construction income increased by $1 \%$ the tax revenues increased by $2.7117 \%$ With other factors remaining constant. This is due to that the construction sector is considered one of the important sectors in the Jordanian economy. It provides the necessary infrastructure for many productive and service activities and contributes to job creation, GDP, and state income. The interactions of the construction sector with other economic sectors make it a major industry to promote economic development, thus contributing to income tax revenues, in personal property taxes, licenses, sales and taxes on gross income.

\section{The Impact OF INDUSTRY SECTOR ON Tax REVENUES.}

From table (5) the industry sector (INDUS) has a positive and significant impact on tax revenues in Jordan since the coefficient of industry is 0.6053 and the probability is 0.003 , this means that if industrial production increased by $1 \%$, this will increase tax revenues by $0.6053 \%$ With other factors remaining constant . 
This is due to the fact that the industrial sector is largely owned by entrepreneurs who use better recording activities, giving the tax authority a better taxing capacity in addition industry sector contributes to the creation of employment opportunities, increase the gross domestic product and increase industrial income, which increases direct tax revenues on personal income, corporate income and indirect taxes such as sales tax, licensing, import and export, customs duties and other fees. This result indicates that the increase in industrial sector production and increasing its efficiency will contribute in increasing tax revenues. the study result is consistently with the results of (Ayenew (2016); Basirat, Aboodi and Ahangari (2014); Castro and Camarillo (2014) and Ahmed and Mohammed (2010)).

\section{The Impact of Mining and Quarrying sector on Tax revenues.}

The regression results in table (5) show that the Mining and Quarrying sector (MINQ) has a positive and significant impact on tax revenues. The value of the coefficient is $(0.87884)$ and the probability is $(0.0002)$. This means that if the Mining and Quarrying sector income (MINQ) increased by $1 \%$ this will increase tax revenues by $0.87884 \%$ With other factors remaining constant. This is due to the fact that the mining and quarrying sector is an important sector in the Jordanian economy. It supplies the local industries with the needs of raw materials, providing job opportunities, contributing to increasing exports, reducing imports and increasing the income of individuals, companies and gross domestic product. This increasing direct tax revenue on individuals and businesses and increasing indirect tax revenue such as sales tax, licenses, export fees, etc.

\section{The Impact of Agriculture sector (AGRIC) on Tax Revenues.}

The regression results in table (5) show that the Agriculture sector (AGRIC) has a negative and significant impact on tax revenues. The value of the coefficient is $(-0.53995)$ and the probability is $(0.909)$. This means that if the Agriculture sector (AGRIC) increased by $1 \%$ this will decrease tax revenues by $-0.53995 \%$ With other factors remaining constant. This is due to the fact that the agricultural sector is classified as one of the most difficult sectors to impose the tax due to the small size and spatial spread of agricultural activity and the need to impose taxes by the state taking into account the essential weakness of the agricultural activity to external shocks in addition to the lack of accounting records in the activity, Especially, since the activity is mostly practiced by individuals and not companies. Due to the lack of information on the entry of the agricultural sector and the inability to rely on the self-assessment of income makes it difficult to impose income tax based on self-assessment, resulting in poor results for taxes.

Stotsky and Woldemarian(1997) attributed that in the developing countries it is difficult to impose taxes on the agricultural sector, where a large proportion of workers in agricultural activity is considered the source of subsistence for them, in addition to the existence of a few farmers known for the strict force to impose taxes on a large number of farmers who sell their products in informal markets. Also, Zarra-Nezhad, Ansari Moradi (2016) attributed the negative impact of agriculture share to GDP on tax revenue to that it is difficult to impose taxes on the agricultural sector because a large part of the agricultural sectors are small in size with a limited number of farmers who pay taxes on their income, agricultural products are exempt from indirect taxes, and a large part of the production is consumed and not marketed. It is often difficult to tax the agricultural sector in low-income countries because agricultural activities are small (Agbeyegbe et al., 2004). This result consistently with the results of ( (Zarra-Nezhad, Ansari Moradi (2016); Basirat, Aboodi and Ahangari (2014) and Castro and Camarillo (2014) and differently with the results of( (Ahmed and Mohammed (2010) and Gupta (2007)).

\section{The Impact Of Services Sector on Tax Revenues.}

The regression results in table (5) show that the services sector (Services) has a positive and significant impact on tax revenues. The value of the coefficient is $(0.55031)$ and the probability is $(0.0011)$. This means that if the services sector income (Services) increased by $1 \%$ this will increase tax revenues by $0.55031 \%$ With other factors remaining constant. This is due to the fact that the services sector represented by (transportation, communications and water and electricity, tourism, education, health and services, financial and logistical support). is the largest participate in GDP and the largest employer in Jordan as well as in most countries and It can export its services through consumer access to tourism, education, health and services, financial and logistical support. It is the only supporter of the productive links of the agriculture and industrial sectors through the various infrastructure channels. all of that makes the services sector increasing direct tax revenue on individuals and businesses and increasing indirect tax revenue such as sales tax, licenses and fees. The result of this study is consistently with result of Ahmed and Mohammed (2010). 
As shown by the value of the adjusted determinant coefficient, that $65 \%$ of the changes in tax revenues are due to both independent variables, as evidenced by the value of $\mathrm{F}$ and its significance that the model is valid for measuring the causal relationship between the independent variables and the dependent variable.

Table 5: Multiple Linear Regression Results

\begin{tabular}{|l|l|l|l|l|}
\hline & $\begin{array}{l}\text { Dependent Variable } \\
\text { D(TAX) }\end{array}$ & & & \\
\hline Independent Variable & Coefficient & Std. Error & t-Statistic & Prob. \\
\hline $\mathrm{C}$ & 0.00029 & 0.001503 & 0.192778 & 0.8492 \\
\hline $\mathrm{D}(\mathrm{CONS})$ & -2.71177 & 1.107398 & -2.44878 & 0.0242 \\
\hline $\mathrm{D}($ INDS) & -0.6053 & 0.178006 & -3.40047 & 0.003 \\
\hline $\mathrm{D}($ MINQ) & -0.87884 & 0.191512 & -4.58894 & 0.0002 \\
\hline $\mathrm{D}($ AGRIC) & -0.53995 & 0.303193 & -1.78089 & 0.0909 \\
\hline $\mathrm{D}($ SERVICES) & -0.55031 & 0.143176 & -3.84361 & 0.0011 \\
\hline R-squared & 0.730117 & & & \\
\hline Adjusted R-squared & 0.659095 & & & \\
\hline F-statistic & 10.28017 & & & \\
\hline Prob(F-statistic) & 0.000069 & & & \\
\hline
\end{tabular}

\subsection{Wald Test}

we use Wald test to check whether the independent variables ( $\mathrm{D}(\mathrm{CONS}), \mathrm{D}$ (INDS), $\mathrm{D}(\mathrm{MINQ}), \mathrm{D}$ (AGRIC), $\mathrm{D}$ (SERVICES)) have a significant impact on tax revenues (TAX) or not. The result in table (6) shows that the independent variables have a significant impact on tax revenues since the test statistic value of Chi-square is and (33.38573) the probability of it is 0.0004 .

Table 6:Wald Test Results

\begin{tabular}{|l|l|l|l|}
\hline Test Statistic & Value & df & Probability \\
F-statistic & 8.346432 & $(4,21)$ & 0.0003 \\
\hline Chi-square & 33.38573 & 4 & 0 \\
\hline
\end{tabular}

Null Hypothesis: $\mathrm{C}(2)=\mathrm{C}(3)=\mathrm{C}(4)=\mathrm{C}(5)=\mathrm{C}(6)=0$

\subsection{Diagnostic Checking for the Model}

We have test the model to make sure that the model is suitable for the requirement of the good regression model.

\subsubsection{Autocorrelation Test}

Autocorrelation or serial correlation occurs when the error term observations in a regression are correlated. Autocorrelation is a problem because its existence means that useful information is missing from the model. Such information might explain the variation in the dependent variable more precisely (Gujarati, 2012).

The Breusch-Godfrey Serial Correlation LM Test is used to check whether there is autocorrelation between the error term of the observations in a regression or not. The results in Table (7) shows that the Obs-R-squared probability is more than $5 \%$ which means that there is no auto-correlation between the error term of the observations.

Table (7) Results of Autocorrelation Test

\begin{tabular}{|l|l|l|}
\hline $\begin{array}{l}\text { Breusch - Godfrey Serial } \\
\text { Correlation LM test }\end{array}$ & Probability \\
\hline F-Statistic & 0.883945 & 0.3596 \\
\hline Obs-R-Square & 1.170233 & 0.2794 \\
\hline
\end{tabular}

\subsubsection{Heteroskedasti city Test}

one of the linear regression assumptions is that the variance of the error term should be constant since the confidence intervals and hypotheses test related to the model depends on this assumption, if the variance of the error term is not constant this will lead to an in efficient regression( Stewart, 1991). Breusch-Pagan-Godfrey test is used to check whether the error term of the residuals of the model is Heteroskedasticity or not. The result in Table (8) shows that the Obs- R-squared probability is 0.7506 which is more than $5 \%$ and this means that the residuals of the model are not Heteroskedasticity or they are homoskedasticity. 
Table (8) Results of the Heteroskedasticity Test

\begin{tabular}{|l|l|l|}
\hline Heteroskedasticity Test & Breusch-Pagan-Godfrey & Probability \\
\hline F-Statistic & 0.454468 & 0.8049 \\
\hline Obs-R-Square & 2.670533 & 0.7506 \\
\hline Scaled Explained & 1.864794 & 0.8675 \\
\hline
\end{tabular}

\subsubsection{Histogram-Normality Test}

We used Histogram-Normality Test to check whether the model residuals are normally distributed or not. The result in table (9) shows that the probability of Jarque-Bera is more than 5\%, which means that the model residuals are normally distributed.

Table 9. Histogram-Normality Test

Series : Residuals

Sample 1992-2016

Observations 25

Jarque-Pera 1.792783

Probability 0.408039

\section{Conclusions}

This study examined the impact of construction sector value added share of GDP (CONS), industry sector value added share of GDP(INDS), mining and quarrying sector value added share of GDP (MINQ), agriculture sector value added share of GDP (AGRIC), and services sector value added share of GDP (SERVICES. By using annually time series data for the period (1990-2016). The study used unit root test, Co-integration test, multiple linear regression model and wald test to examine the study hypotheses. The regression results indicate that there are significant differences in the impact of economic sectors value added share of GDP on tax revenues in Jordan. A number of conclusions can be drawn from the this study.

1- The Construction Sector value added share of GDP has a positive and significant impact on tax revenues in Jordan. This is due to that the construction sector contributes effectively in the Jordanian economy and thus contributes positively to the tax revenues through direct and indirect taxes.

2- The industry sector value added share of GDP (INDS) has a positive and significant impact on tax revenues in Jordan. This is attributed to that the industry sector (INDUS) contributes significantly to GDP, which that the increasing the value added of this sector increases the direct taxes on the income of industrial companies as well as increases indirect taxes such as sales tax. Also, industry scoter increasing direct and indirect employment opportunities in the economy which increases the taxes on personal income and the scoter increases customs duties and license fees.

3- The Mining and Quarrying sector Value added share of GDP has a positive and significant impact on tax revenues. This is due to the fact that the mining and quarrying sector plays a vital role in the Jordan economy, since it supplies the various industries with inputs and contributes in increasing the income of individuals, companies and GDP and participate in a significant way in increasing tax revenues through direct tax on income of individuals and companies and through indirect taxes such as sales tax and license fees and exports and imports fees and customs duties.

4- The agriculture sector (AGRIC) value added share of GDP has a negative and significant impact on tax revenues, This is due to the fact that the small size of the cultivated areas and the wide spread of the agricultural sector and the practice of large by individuals rather than companies and did not provide accounting records that explain the income and the inability of the government to impose income tax depends on the self-assessment of workers in the agricultural sector, especially that the exchange is in cash and not through the banking system making the application process difficult.

5- The services sector value added share of GDP has a positive and significant impact on tax revenues. This is due to the fact that the services sector, with its various components, is one of the most economical sectors contributing to the GDP and the most in terms of job opportunities, as it contributes to the provision of services for the industrial and agricultural sectors. Making the sector an effective contributor to direct and indirect tax revenues, license fees and other fees paid to the government. 
Based on the results of the study, the study reached the following recommendations: First, the study has reached a positive and effective impact of the economic sectors ( construction sector, mining and quarrying scoter, industrial sector and services sector) on tax revenues. Therefore, the study recommends the government of Jordan to develop an appropriate economic and investment legislation to encourage these sectors to increase their investments, increase their production and thus increase the various direct and indirect tax revenues. second, The study also recommends the government of Jordan to adopt a moderate tax policy rather than a hard tax policy one, because increasing the taxes burden to a certain level increases production costs, increases prices, this will decrease production, increase employment and decrease the income for companies and individuals, this result in a decrease in tax revenues. Third, the study reached a negative impact of the agricultural sector on tax revenues in Jordan, So, the study recommends the government of Jordan to direct farmers in all their activities to adopt modern production methods that increase production. Taking into consideration this sector provides a large proportion of Jordan's food needs. It also contributes modestly to exports, especially as agricultural production is classified as a strategic production. To increase the income of individuals working in this sector. Then the state can impose an income tax on the large areas that achieve high added value, taking into account that the tax imposed symbolic to ensure the continuity of investment in the agricultural sector and its development.

\section{References}

Agbeyegbe, T., Stotsky, J., and Wolde Mariam, A. ( 2004) Trade Liberalization, exchange rate changes and tax revenue is Sub-Saharan Africa, IMF Working Papaer, WP/07/184.

Ahmad, K. H., Ahmed, S., Mushtaq, M., and Nadeem, M. (2016) Socio Economic Determinants of Tax Revenue in Pakistan: An Empirical Analysis, Journal of Applied Environmental and Biological Sciences, 6(2S)32-42, 2016.

Ahmed, Q. M. and Mohammed S. D. (2010), "Determinant of tax buoyancy: Empirical evidence from developing countries", European Journal of Social Sciences, 13 (3), pp. 408-414.

Amassoma, D. (2011) "External Debt, Internal Debt and Economic Growth Bound in Nigeria using a Causality Approach" Current Research Journal of Social Sciences 3(4): 320-325.

Ayenew, W. (2016), Determinants of tax revenue in Ethiopia (Johansen Co-integration approach), International Journal of Business, Economics and Management, 2016, 3(6): 69-84.

Basirat, M., F. Aboodi and Ahangari., A. (2014), Analyzing the effect of economic variables on total tax revenues in Iran. Asian Economic and Financial Review, Volume 4(6), pp. 755-767.

Begum, L. (2007). A Panel Study on Tax Effort and Tax Buoyancy with Special Reference to Bangladesh. Working Paper Series WP 0715, Policy Analysis Unit, Bangladesh Bank, Dhaka.pp 1-25.

Benoit, K.,( 2011). Linear regression models with logarithmic transformations. London: London School of Economics.

Castro, G, A., and Camarillo, D. B. (2014) Determinants of tax revenue in OECD countries over the period 2001-2011, Contaduría y Administración 59 (3), julio-septiembre 2014: 35-59.

Chaudhry, I, S., and Munir, F. (2010) Determinants of Low Tax Revenue in Pakistan, Pakistan Journal of Social Sciences (PJSS) Vol. 30, No. 2 (December 2010), pp. 439-452.

Gujarati, D, N. (2004), Basic Econometrics, 4th edition, McGraw-Hill.

Gujarati, D. N. (2012) Basic econometrics, 3th Edn, New York, MCGraw-Hill.

Gupta, A. S.(2007) Determinants of tax revenue efforts in developing countries, Journal Of Development Economics, Vol, 48 (2), pp, 315-324.

Hakim, T. A., and Bujang, I. (2011). The Impact and Consequences of Tax Revenues' Components on Economic Indicators: Evidence from Panel Groups Data. International Research Journal of Finance and Economics ISSN 1450-2887 Issue 63 (2011) pp 82-95.

Messere, K.C., and J.P. Owens 1987. International comparisons of tax levels: Pitfalls and insights. OECD Economic Studies 8(Spring):93-119.

Muibi, S.O., and Sinbo, O.O. (2013), Macroeconomic determinants of tax revenue in Nigeria (197-2011), World Applied Sciences Journal, 28 (1), 27-35.

Stewart, J. (1991) Econometrics, New York, Philip Allan.

Stotsky, I. G., and Woldemariam, A. (1997) Tax efforts in Sub-Saharan Africa, IMF Working Paper, No, 107.

Verbeek, M.,( 2004). A guide to modern econometrics. 2nd Edn.: Erasmus University Rotterdam. John Wiley \& Sons, LTD.

Worku, G., (2010). Causal links among saving, investment and growth and determinants of saving in Sub-Saharan Africa: Evidence from Ethiopia. Ethiopian Journal of Economics, 19(2): 1-34.

Zarra-Nezhad, A., M. (2016) Determinants of tax revenue: Does trade liberalization boost or decline, Journal of Economic Cooperation and Development, 37, 2. 